\begin{tabular}{|c|c|c|c|c|c|c|}
\hline \multirow{4}{*}{ Impact Factor: } & ISRA (India) & $=3.117$ & SIS (USA) & $=0.912$ & ICV (Poland) & $=6.630$ \\
\hline & ISI (Dubai, UAE & $=0.829$ & РИНЦ (Russia) & $=0.156$ & PIF (India) & $=1.940$ \\
\hline & GIF (Australia) & $=0.564$ & ESJI (KZ) & $=8.716$ & IBI (India) & $=4.260$ \\
\hline & JIF & $=1.500$ & SJIF (Morocco) & $=5.667$ & OAJI (USA) & $=0.350$ \\
\hline
\end{tabular}

\begin{tabular}{|c|c|}
\hline $\begin{array}{l}\text { SOI: } \underline{1.1 / \mathrm{TA}} \\
\text { International Sc } \\
\text { Theoretical \& A }\end{array}$ & $\begin{array}{l}S \text { DOI: } 10.15863 / T A S \\
\text { ientific Journal } \\
\text { pplied Science }\end{array}$ \\
\hline p-ISSN: 2308-4944 (print) & e-ISSN: 2409-0085 (online) \\
\hline Year: 2019 Issue: 06 & Volume: 74 \\
\hline Published: 15.06 .2019 & http://T-Science.org \\
\hline
\end{tabular}

SECTION 9: Chemistry and chemical technology
QR - Issue

QR - Article

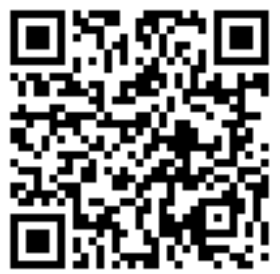

Oleg Ivanovych Yurchenko Kharkiv V.N. Karazin National University, PhD, Full Professor of

Chemical Metrology Department, yurchenko@karazin.ua

Tetyana Vasylivna Chernozhuk Kharkiv V.N. Karazin National University, $\mathrm{PhD}$, Associate Professor of Inorganic Chemistry Department, tanya.chernozhuk@gmail.com

Oleksii Andriovych Kravchenko Kharkiv V.N. Karazin National University, $\mathrm{PhD}$, Associate Professor of Chemical Metrology Department, alekseykravch@ukr.net

\title{
ATOMIC ABSORPTION AND ATOMIC EMISSION WITH INDUCTIVE CONNECTED PLASMA DETERMINATION OF ZINC, IRON AND MANGANESE IN SALT MINES OF BAHMUT CITY
}

\begin{abstract}
Sensitivity and accuracy of atomic-absorption and atomic-emission with inductive connected plasma determination of the analytes in the salt samples, using ultrasound treatment, surface active substances (Triton X100) and new standard composition samples, based on acetylacetonates of metals, was increased. An influence of Triton X-100 concentration ant time of ultrasound treatment on the magnitude of analytical signal of the determined analytes was investigated. It was shown that maximal analytical signal occurs at $\omega$ of (Triton X-100) $=3 \%$ and ultrasound treatment during 20 minutes. Content of Zinc, Iron and Manganese was determined by two methods. An accuracy of the results of atomic-absorption measurements was checked by the "injected-found out" method. An absence of the systematic error was determined by variation of masses of the samples. The results, obtained by two methods, were compared. It was proved that run of the means is not sufficient and proved by random scatter. The limit of the analytes determination by atomic-absorption method is lower, than corresponding data from literature.

Key words: Iron, Zinc, Manganese, atomic-absorption and atomic-emission with inductive connected plasma spectroscopy, sample preparation, Triton X-100, ultrasound, standard composition samples, metrological characteristics

Language: English

Citation: Yurchenko, O. I., Chernozhuk, T. V., \& Kravchenko, O. A. (2019). Atomic absorption and atomic emission with inductive connected plasma determination of zinc, iron and manganese in salt mines of Bahmut city. ISJ Theoretical \& Applied Science, 06 (74), 179-185.

\section{Soi: http://s-o-i.org/1.1/TAS-06-74-19 Doi: crossef https://dx.doi.org/10.15863/TAS.2019.06.74.19}

\section{Introduction}

Chemical pollution is a global concern for environmental and food safeties. Heavy metals affect the functioning of the central nervous system, change the composition of the blood and disrupt the functions of organs. The negative ecological situation is

processes, weathering), so as by indirect anthropogenic action [1,p.610]. The trace elements are an important aspect of the quality of food, and also can cause a carcinogenic effect on living organisms [2, p.123; 3, p.112; 4, p.405], so it is necessary to establish control over their content [2,p.79].
\end{abstract} influenced by direct anthropogenic action (biological 


\begin{tabular}{|c|c|c|c|c|c|c|}
\hline \multirow{4}{*}{ Impact Factor: } & ISRA (India) & $=3.117$ & SIS (USA) & $=0.912$ & ICV (Poland) & $=6.630$ \\
\hline & ISI (Dubai, UAE & $=0.829$ & РИНЦ (Russia & $=0.156$ & PIF (India) & $=1.940$ \\
\hline & GIF (Australia) & $=0.564$ & ESJI (KZ) & $=8.716$ & IBI (India) & $=4.260$ \\
\hline & JIF & $=1.500$ & SJIF (Morocce & $=5.667$ & OAJI (USA) & $=0.350$ \\
\hline
\end{tabular}

\section{Materials and Methods}

Sodium chloride is the most important raw material for industry and the most essential kind of nutrition. Salt is a regulator of osmotic pressure, water exchange, and necessary for the formation of hydrochloric acid in the process of gastric secretion and activates enzymes. Zinc, Manganese, and Iron are biologically active analytes. According to supplement No. 3 due to the sanitary-anti-epidemic and sanitaryanti-toxicological rules of health and hygiene rules and standards (HaHRaS) of Ukraine 42-123-4089 standards, the content of zinc in the kitchen salt should not exceed $10 \mathrm{mg} / \mathrm{kg}$, and the contents of Manganese and Iron are not regulated [3,p.112].

However, at present, there are no standard methods for determining Zinc, Manganese, and Iron. The literature describes the methods for determining analytes in various multicomponent samples by modern analytical methods: atomic absorption spectroscopy [4,p.407; 5,p.6620;6,p.12], atomic emission spectroscopy with inductively coupled plasma [7,p.365;8,p.332], mass-spectroscopy with inductively coupled plasma [9,p.3;10,p.164;11,p.20], $\mathrm{X}$-ray fluorescence analysis [12,p.7864;13,p.7; 14,p.320;15,p.4537]. An important role in the analysis of multicomponent systems is played by modern methods of sample preparation of the analyzed samples $\quad[16$, p.4;17,p.3;18,p.10;19,p.5;20,p.5691; 21,p.607;22,p.346]. Reliable determination of trace elements in samples is necessary because they influence on human health [23,p.4;24,p.395; 25,p.110;26,p.4].

The goal of our work is to develop a competitive method of atomic absorption and atomic emission with inductively coupled plasma for the determination of analytes in multicomponent samples using ultrasonic processing, surfactants, and metal acetylacetonates as standard samples of the composition.

\section{Experimental}

The atomic absorption spectrometer C-115M-1 (flame-acetylene-air) and hollow cathode lamps were used in this work. Measurements were carried out at the following wavelengths $\lambda \mathrm{nm}$ : for $\mathrm{Zn}-213.86$; Fe259.94; Mn-257.61. To account for the effect of nonresonance (nonselective) absorption, the deuterium background correction was used. An atomic emission spectrometer with an inductively coupled plasma iCAP 6300 Duo, Thermo Scientific, USA was used. Parameters of determination of Zinc, Iron and Manganese by the method of atomic emission spectrometry with inductively coupled plasma are represented as follows: the rate of plasmaforming flow of argon-12 1/min; plasma power- 1350 $\mathrm{W}$; speed of the auxiliary flow of argon- $1.5 \mathrm{1} / \mathrm{min}$; plasma-axial monitoring mode was taken; flow of argon at flux-0.55 1/min; pump speed-50 rpm; integration time of signal-20s; 5 parallel measurements were taken.

Ultrasonic bath PS-20, power of $120 \mathrm{~W}$ with a frequency of $40 \mathrm{kHz}$, laboratory weights OHAUS PA $(65 / 0.0001 \mathrm{~g})$, Triton X-100 $\mathrm{C}_{14} \mathrm{H}_{22} \mathrm{O}\left(\mathrm{C}_{2} \mathrm{H}_{4} \mathrm{O}\right)_{\mathrm{n}}$, where $\mathrm{n}=9-10, M_{r} \sim 646 \mathrm{~g} / \mathrm{mol}$, CMC (critical micelle concentration $)=2.9 \cdot 10^{-4} \mathrm{~mol} / \mathrm{l}$, acetylacetone, zinc, Iron and manganese acetylacetonates. The initial concentration of metal solutions for the preparation of solutions of solvents is $0.1 \mathrm{~g} / \mathrm{l}$. Standard samples of solutions of Zinc, Iron, and Manganese with a concentration of $1 \mathrm{~g} / \mathrm{l}$ are made at the PhysicoChemical Institute of the National Academy of Sciences of Ukraine (Odesa). When using experimental work, distilled water and chemical reagents of qualification are used not lower than ch.p. (chemically pure).

Samples from saline deposits weighing $0.3 \mathrm{~g}$ (weighed with deviation $0.0001 \mathrm{~g}$ ) were dissolved in $10 \mathrm{ml}$ of $1.5 \%$ nitric acid (an optimal analytical signal with a flame atomic absorption determination of the analytes), sonicated for 20 minutes, and $2 \mathrm{ml}$ was added. Triton X-100 with $\omega=3 \% ; 0.5 \mathrm{ml}$ acetylacetone, were thoroughly mixed and quantitatively transferred to a $25 \mathrm{ml}$ flask.

Four samples from the salt deposits of the city of Bakhmut - mine No. 1, 3, section 3 (marked as sample No. 1); mine number 4 (sample No. 2); mine №7 (sample No. 3) and the Volodarsky mine (sample No. 4). Of each sample, five samples were selected for analysis.

\section{Results and discussion}

The study of the influence of Triton X-100 on the magnitude of the analytical signal, depending on the concentration of surfactant (Table 1), was carried out.

As can be seen from Table 1, the greatest value of the analytical signal at atomic absorption determination of analytes is achieved using Triton X100 with $\omega=3 \%$.

Adding aqueous solutions of Triton X-100 with $\omega=3 \%$ to solution samples decreases the surface tension of solutions decreases and the dispersion of the solution increases, which in the flame atomic adsorption leads to complete atomization of solutions and increases the sensitivity of the determination of analytes from 1.6 to 2.0 times. Sensitivity is determined by the formula:

$$
S=\operatorname{tg} \alpha=\frac{d A}{d C} .
$$

The rise in the sensitivity of the definitions compared with water solutions and solutions treated with ultrasound with additives Triton X-100:

$$
\Delta S=\frac{\operatorname{tg} \alpha_{1}}{\operatorname{tg} \alpha_{2}},
$$




\begin{tabular}{|c|c|c|c|c|c|c|}
\hline \multirow{4}{*}{ Impact Factor: } & ISRA (India) & $=3.117$ & SIS (USA) & $=0.912$ & ICV (Poland) & $=6.630$ \\
\hline & ISI (Dubai, UAE & $=0.829$ & РИНЦ (Russia & $=0.156$ & PIF (India) & $=1.940$ \\
\hline & GIF (Australia) & $=0.564$ & ESJI (KZ) & $=8.716$ & IBI (India) & $=4.260$ \\
\hline & JIF & $=1.500$ & SJIF (Morocce & $=5.667$ & OAJI (USA) & $=0.350$ \\
\hline
\end{tabular}

Metal acetylacetonates are formed in the solution by adding acetylacetone to this solution. Therefore, using metal $\beta$-diketonates as standard samples of the composition, we increase the precision and accuracy of the analysis, as the analyzed substances in the chemical composition are similar to the calibration.

The influence of the time of ultrasound sample processing on the size of the analytical signal under atomic absorption determination of the analytes (Table 2) was also investigated.

It is shown that the greatest value of the analytical signal at atomic absorption determination of analytes is achieved by ultrasound processing for 20 minutes.

The content of analytes in samples of sodium chloride was determined by methods of atomic absorption and atomic emission spectroscopy with inductively coupled plasma (Table 3-4).

The verification of the correctness of the results of the determination of analytes by the atomic absorption method was carried out by the method "introduced-found" (Table 5).

Methyl acetylacetonates were added to the sample mass, and then all the stages of the sampling preparation, which are described in the experimental part, were passed by the samples.

The consistency of the results of determination of analytes by atomic absorption and atomic emission techniques with inductively coupled plasma spectroscopy in samples of stone salt was carried out according to Fisher and Student's t-test, which is the verification of the correctness of the results of the analysis. (Table 6).

It was found out that the difference between the meanings is not significant and is justified by random distribution.

The systematic error of the results at atomic absorption determination of the analytes by the variation of the weight of sample weight is estimated (Table 7).

By varying the mass of sample weights, it is shown that there is no significant systematic error.

The boundary of detection of analytes by an atomic absorption method is estimated in the abovementioned methodology. For 20 blank samples, the analytical signal (A) was determined, the standard deviation of the background was calculated according to the formula

$$
S_{0}=\sqrt{\frac{\sum(\bar{A}-A)^{2}}{n-1}}
$$

Then the limit of detection of analytes was calculated

$$
\mathrm{C}_{\min }=\frac{3 S_{0}}{S}
$$

Detection of Zinc, Iron, and Manganese by AAS method is for Zinc - $0.001 \mu \mathrm{g} / \mathrm{ml}$, Iron - $0.003 \mu \mathrm{g} / \mathrm{ml}$, Manganese - $0.001 \mu \mathrm{g} / \mathrm{ml}$, respectively, which are listed below in the periodical literature.

The limits of the detection of AES-ICP for Zinc - $0.002 \mu \mathrm{g} / \mathrm{ml}$, Iron - $0.002 \mu \mathrm{g} / \mathrm{ml}$, manganese - 0.001 $\mu \mathrm{g} / \mathrm{ml}$, which are listed below in the periodical literature.

\section{Conclusions}

The method of atomic absorption and atomic emission with inductively coupled plasma with improved metrological characteristics has been developed by using ultrasonic testing, aqueous solutions of Triton $\mathrm{X}-100$ and acetylacetonate analytes as standard samples of the composition.

Table 1. Selection of the Triton X-100 concentration for the atomic absorption determination of Zinc, Iron

\begin{tabular}{|c|c|c|c|c|c|c|c|c|}
\hline \multirow[b]{2}{*}{$\begin{array}{l}\omega(\text { Triton } \\
\mathrm{X}-100), \%\end{array}$} & \multicolumn{2}{|l|}{ Sample №1 } & \multicolumn{2}{|l|}{ Sample №2 } & \multicolumn{2}{|l|}{ Sample №3 } & \multicolumn{2}{|l|}{ Sample №4 } \\
\hline & $\begin{array}{l}C, \mathrm{mg} / \mathrm{\kappa g} \\
\bar{C} \pm \frac{t_{p, f} S}{\sqrt{n}}\end{array}$ & $S_{r}$ & $\begin{array}{l}C, \mathrm{mg} / \mathrm{\kappa g} \\
\quad \bar{C} \pm \frac{t_{p, f} S}{\sqrt{n}}\end{array}$ & $S_{r}$ & $\begin{array}{c}C, \quad \mathrm{mg} / \mathrm{kg} \\
\bar{C} \pm \frac{t_{p, f} S}{\sqrt{n}}\end{array}$ & $S_{r}$ & 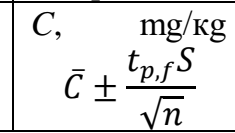 & $S_{r}$ \\
\hline \multicolumn{9}{|c|}{ Zinc } \\
\hline $3 \%$ & $10.86 \pm 0.02$ & 0.01 & $8.03 \pm 0.03$ & 0.01 & $8.43 \pm 0.04$ & 0.01 & $8.29 \pm 0.02$ & 0.01 \\
\hline $4 \%$ & $9.05 \pm 0.04$ & 0.01 & $7.50 \pm 0.02$ & 0.01 & $7.33 \pm 0.02$ & 0.01 & $7.59 \pm 0.03$ & 0.01 \\
\hline $5 \%$ & $8.52 \pm 0.01$ & 0.01 & $7.15 \pm 0.03$ & 0.01 & $6.95 \pm 0.03$ & 0.01 & $7.23 \pm 0.04$ & 0.01 \\
\hline $6 \%$ & $8.19 \pm 0.02$ & 0.01 & $6.86 \pm 0.03$ & 0.01 & $6.54 \pm 0.03$ & 0.01 & $6.69 \pm 0.04$ & 0.01 \\
\hline \multicolumn{9}{|l|}{ Iron } \\
\hline$\omega, \%$ & \multicolumn{2}{|l|}{ Sample №1 } & \multicolumn{2}{|l|}{ Sample №2 } & \multicolumn{2}{|l|}{ Sample №3 } & \multicolumn{2}{|l|}{ Sample №4 } \\
\hline $3 \%$ & $7.23 \pm 0.03$ & 0.01 & $8.90 \pm 0.04$ & 0.01 & $10.06 \pm 0.03$ & 0.01 & $12.16 \pm 0.01$ & 0.01 \\
\hline
\end{tabular}
and Manganese $(n=5, P=0.95)$. 


\begin{tabular}{|c|c|c|c|c|c|c|}
\hline \multirow{4}{*}{ Impact Factor: } & ISRA (India) & $=3.117$ & SIS (USA) & $=0.912$ & ICV (Poland) & $=6.630$ \\
\hline & ISI (Dubai, UAE & $=0.829$ & РИНЦ (Russia) & $=0.156$ & PIF (India) & $=1.940$ \\
\hline & GIF (Australia) & $=0.564$ & ESJI (KZ) & $=8.716$ & IBI (India) & $=4.260$ \\
\hline & JIF & $=1.500$ & SJIF (Morocco) & $=5.667$ & OAJI (USA) & $=0.350$ \\
\hline
\end{tabular}

\begin{tabular}{|l|l|l|l|l|l|l|l|l|}
\hline $4 \%$ & $7.05 \pm 0.02$ & 0.01 & $8.26 \pm 0.03$ & 0.01 & $9.51 \pm 0.02$ & 0.01 & $11.58 \pm 0.02$ & 0.01 \\
\hline $5 \%$ & $6.25 \pm 0.03$ & 0.01 & $7.83 \pm 0.04$ & 0.01 & $8.94 \pm 0.02$ & 0.01 & $10.84 \pm 0.04$ & 0.01 \\
\hline $6 \%$ & $5.79 \pm 0.03$ & 0.01 & $7.06 \pm 0.02$ & 0.01 & $8.47 \pm 0.04$ & 0.01 & $9.68 \pm 0.02$ & 0.01 \\
\hline \multicolumn{7}{|l|}{ Manganese } \\
\hline$\omega, \%$ & Sample №1 & \multicolumn{1}{|l|}{ Sample №2 } & \multicolumn{1}{l|}{ Sample №3 } & \multicolumn{2}{l|}{ Sample №4 } \\
\hline $3 \%$ & $2.86 \pm 0.02$ & 0.01 & $2.37 \pm 0.01$ & 0.01 & $3.48 \pm 0.03$ & 0.01 & $3.40 \pm 0.01$ & 0.01 \\
\hline $4 \%$ & $2.48 \pm 0.03$ & 0.01 & $2.17 \pm 0.02$ & 0.01 & $3.05 \pm 0.03$ & 0.01 & $3.19 \pm 0.01$ & 0.01 \\
\hline $5 \%$ & $2.05 \pm 0.02$ & 0.01 & $1.87 \pm 0.01$ & 0.01 & $2.74 \pm 0.02$ & 0.01 & $2.65 \pm 0.02$ & 0.01 \\
\hline $6 \%$ & - & - & - & - & - & - & - & - \\
\hline
\end{tabular}

Table 2. Choose of time of ultrasound treatment at atomic absorption determination of Zinc, Iron and Manganese $(n=5, P=0.95)$.

\begin{tabular}{|c|c|c|c|c|c|c|c|c|}
\hline \multirow[b]{2}{*}{ US, min. } & \multicolumn{2}{|l|}{ Sample №1 } & \multicolumn{2}{|l|}{ Sample №2 } & \multicolumn{2}{|l|}{ Sample №3 } & \multicolumn{2}{|l|}{ Sample №4 } \\
\hline & $\begin{array}{l}C, \mathrm{mg} / \mathrm{\kappa g} \\
\bar{C} \pm \frac{t_{p, f} S}{\sqrt{n}}\end{array}$ & $S_{r}$ & $\begin{array}{l}C, \mathrm{mg} / \mathrm{\kappa g} \\
\quad \bar{C} \pm \frac{t_{p, f} S}{\sqrt{n}}\end{array}$ & $S_{r}$ & $\begin{array}{l}C, \mathrm{mg} / \mathrm{\kappa g} \\
\bar{C} \pm \frac{t_{p, f} S}{\sqrt{n}}\end{array}$ & $S_{r}$ & $\begin{array}{l}C, \mathrm{mg} / \mathrm{Kg} \\
\bar{C} \pm \frac{t_{p, f} S}{\sqrt{n}}\end{array}$ & $S_{r}$ \\
\hline \multicolumn{9}{|l|}{ Zinc } \\
\hline 10 & $7.23 \pm 0.03$ & 0.01 & $7.91 \pm 0.03$ & 0.01 & $7.65 \pm 0.03$ & 0.01 & $8.25 \pm 0.02$ & 0.01 \\
\hline 15 & $10.44 \pm 0.04$ & 0.01 & $8.26 \pm 0.02$ & 0.01 & $8.38 \pm 0.03$ & 0.01 & $8.72 \pm 0.04$ & 0.01 \\
\hline 20 & $12.29 \pm 0.02$ & 0.01 & $8.61 \pm 0.03$ & 0.01 & $9.40 \pm 0.01$ & 0.01 & $9.84 \pm 0.04$ & 0.01 \\
\hline 25 & $11.83 \pm 0.03$ & 0.01 & $8.20 \pm 0.02$ & 0.01 & $8.47 \pm 0.03$ & 0.01 & $9.49 \pm 0.03$ & 0.01 \\
\hline \multicolumn{9}{|l|}{ Iron } \\
\hline $\begin{array}{l}\text { US, } \\
\text { min. }\end{array}$ & \multicolumn{2}{|l|}{ Sample №1 } & \multicolumn{2}{|l|}{ Sample №2 } & \multicolumn{2}{|l|}{ Sample №3 } & \multicolumn{2}{|l|}{ Sample №4 } \\
\hline 10 & $7.23 \pm 0.03$ & 0.01 & $8.90 \pm 0.02$ & 0.01 & $10.06 \pm 0.01$ & 0.01 & $12.16 \pm 0.04$ & 0.01 \\
\hline 15 & $9.45 \pm 0.02$ & 0.01 & $12.54 \pm 0.03$ & 0.01 & $13.72 \pm 0.04$ & 0.01 & $15.93 \pm 0.03$ & 0.01 \\
\hline 20 & $11.68 \pm 0.03$ & 0.01 & $14.04 \pm 0.03$ & 0.01 & $15.59 \pm 0.03$ & 0.01 & $17.89 \pm 0.03$ & 0.01 \\
\hline 25 & $6.76 \pm 0.01$ & 0.01 & $10.74 \pm 0.02$ & 0.01 & $13.30 \pm 0.04$ & 0.01 & $14.12 \pm 0.02$ & 0.01 \\
\hline \multicolumn{9}{|c|}{ Manganese } \\
\hline $\begin{array}{l}\text { US, } \\
\text { min. }\end{array}$ & \multicolumn{2}{|l|}{ Sample №1 } & \multicolumn{2}{|l|}{ Sample №2 } & \multicolumn{2}{|l|}{ Sample №3 } & \multicolumn{2}{|l|}{ Sample №4 } \\
\hline 10 & $2,86 \pm 0,03$ & 0.01 & $2.37 \pm 0.02$ & 0.01 & $3.48 \pm 0.04$ & 0.01 & $3.40 \pm 0.03$ & 0.01 \\
\hline 15 & $2,96 \pm 0,03$ & 0.01 & $2.42 \pm 0.03$ & 0.01 & $3.79 \pm 0.03$ & 0.01 & $3.61 \pm 0.03$ & 0.01 \\
\hline 20 & $3,14 \pm 0,03$ & 0.01 & $2.78 \pm 0.03$ & 0.01 & $4.27 \pm 0.04$ & 0.01 & $3.75 \pm 0.04$ & 0.01 \\
\hline 25 & $3,05 \pm 0,02$ & 0.01 & $2.59 \pm 0.04$ & 0.01 & $4.03 \pm 0.03$ & 0.01 & $3.54 \pm 0.03$ & 0.01 \\
\hline
\end{tabular}

Table 3. Results of atomic absorption determination of Zinc, Iron and Manganese using Triton X-100 ( $\omega=$ $3 \%)$, stabilized by ultrasound $(n=5, P=0.95)$.

\begin{tabular}{|l|l|l|}
\hline Name of the sample & \multicolumn{1}{|c|}{$\begin{array}{c}\text { Concentration, } \mathrm{mg} / \mathrm{Kg} \\
\bar{C} \pm \frac{t_{p, f} S}{\sqrt{n}}\end{array}$} & \multicolumn{2}{l|}{$S_{r}$} \\
\hline Zinc & \multicolumn{2}{|c|}{} \\
\hline Mine № 1,3 & $12.29 \pm 0.05$ & 0.01 \\
\hline Mine № 4 & $8.61 \pm 0.04$ & 0.01 \\
\hline Mine № 7 & $9.40 \pm 0.05$ & 0.01 \\
\hline Mine of Volodarsky & $9.84 \pm 0.03$ & 0.01 \\
\hline Iron & $11.68 \pm 0.06$ & 0.01 \\
\hline Mine № 1,3 & $14.04 \pm 0.05$ & 0.01 \\
\hline Mine № 4 &
\end{tabular}




\begin{tabular}{llllll} 
& ISRA (India) $=\mathbf{3 . 1 1 7}$ & SIS (USA) & $=\mathbf{0 . 9 1 2}$ & ICV (Poland) & $=\mathbf{6 . 6 3 0}$ \\
Impact Factor: & ISI (Dubai, UAE) $=\mathbf{0 . 8 2 9}$ & PUHL (Russia) $=\mathbf{0 . 1 5 6}$ & PIF (India) & $=\mathbf{1 . 9 4 0}$ \\
& GIF (Australia) $=\mathbf{0 . 5 6 4}$ & ESJI (KZ) $=\mathbf{8 . 7 1 6}$ & IBI (India) & $=\mathbf{4 . 2 6 0}$ \\
& JIF & $\mathbf{1 . 5 0 0}$ & SJIF (Morocco) $=\mathbf{5 . 6 6 7}$ & OAJI (USA) & $\mathbf{0 . 3 5 0}$ \\
\hline
\end{tabular}

\begin{tabular}{|l|l|l|}
\hline Mine № 7 & $15.59 \pm 0.04$ & 0.01 \\
\hline Mine of Volodarsky & $17.87 \pm 0.05$ & 0.01 \\
\hline Manganese & $3.14 \pm 0.05$ & 0.01 \\
\hline Mine № 1,3 & $2.78 \pm 0.03$ & 0.01 \\
\hline Mine № 4 & $4.27 \pm 0.05$ & 0.01 \\
\hline Mine № 7 & $3.75 \pm 0.04$ & 0.01 \\
\hline Mine of Volodarsky &
\end{tabular}

Table 4. Results of atomic emission with inductively coupled plasma for the determination of Zinc, Iron and Manganese using Triton $X-100(\omega=3 \%)$, stabilized by ultrasound $(n=5, P=0.95)$.

\begin{tabular}{|c|c|c|}
\hline Name of the sample & $\begin{array}{r}\text { Concentration, } \mathrm{mg} / \mathrm{Kg} \\
\bar{C} \pm \frac{t_{p, f} S}{\sqrt{n}}\end{array}$ & $S_{r}$ \\
\hline \multicolumn{3}{|c|}{ vit } \\
\hline Mine № 1,3 & $12.33 \pm 0.04$ & 0.01 \\
\hline Mine № 4 & $8.65 \pm 0.04$ & 0.01 \\
\hline Mine № 7 & $9.42 \pm 0.05$ & 0.01 \\
\hline Mine of Volodarsky & $9.87 \pm 0.02$ & 0.01 \\
\hline \multicolumn{3}{|l|}{ Iron } \\
\hline Mine № 1,3 & $11.71 \pm 0.04$ & 0.01 \\
\hline Mine № 4 & $14.08 \pm 0.03$ & 0.01 \\
\hline Mine № 7 & $15.62 \pm 0.05$ & 0.01 \\
\hline Mine of Volodarsky & $17.90 \pm 0.05$ & 0.01 \\
\hline \multicolumn{3}{|l|}{ Manganese } \\
\hline Mine № 1,3 & $3.17 \pm 0.05$ & 0.01 \\
\hline Mine № 4 & $2.81 \pm 0.05$ & 0.01 \\
\hline Mine № 7 & $4.28 \pm 0.05$ & 0.01 \\
\hline Mine of Volodarsky & $3.77 \pm 0.04$ & 0.01 \\
\hline
\end{tabular}

Table 5. Checking the correctness of the results of the atomic absorption determination of Zinc, Iron and Manganese by the method "introduced-found" $(n=5, P=0.95)$.

\begin{tabular}{|c|c|c|c|c|}
\hline Name of the sample & Contain, $\mathrm{mg} / \mathrm{kg}$ & Injected, $\mathrm{mg} / \mathrm{kg}$ & Found out, $\mathrm{mg} / \mathrm{kg}$ & $S_{r}$ \\
\hline \multicolumn{5}{|l|}{ Zinc } \\
\hline Mine № 1,3 & $12.29 \pm 0.05$ & 15 & $27.35 \pm 0.05$ & 0.01 \\
\hline Mine № 4 & $8.61 \pm 0.04$ & 10 & $18.63 \pm 0.03$ & 0.01 \\
\hline Mine № 7 & $9.40 \pm 0.05$ & 10 & $19.38 \pm 0.04$ & 0.01 \\
\hline Mine of Volodarsky & $9.84 \pm 0.03$ & 10 & $19.85 \pm 0.05$ & 0.01 \\
\hline \multicolumn{5}{|l|}{ Iron } \\
\hline Mine № 1,3 & $11.68 \pm 0.06$ & 10 & $21.65 \pm 0.05$ & 0.01 \\
\hline Mine № 4 & $14.04 \pm 0.05$ & 15 & $29.03 \pm 0.05$ & 0.01 \\
\hline Mine № 7 & $15.59 \pm 0.04$ & 15 & $30.63 \pm 0.03$ & 0.01 \\
\hline Mine of Volodarsky & $17.87 \pm 0.05$ & 20 & $37.84 \pm 0.05$ & 0.01 \\
\hline \multicolumn{5}{|l|}{ Manganese } \\
\hline Mine № 1,3 & $3.14 \pm 0.05$ & 5 & $8.15 \pm 0.04$ & 0.01 \\
\hline Mine № 4 & $2.78 \pm 0.03$ & 5 & $7.59 \pm 0.05$ & 0.01 \\
\hline Mine № 7 & $4.27 \pm 0.05$ & 5 & $9.27 \pm 0.04$ & 0.01 \\
\hline Mine of Volodarsky & $3.75 \pm 0.04$ & 5 & $8.73 \pm 0.05$ & 0.01 \\
\hline
\end{tabular}




\begin{tabular}{llllll} 
& ISRA (India) $=\mathbf{3 . 1 1 7}$ & SIS (USA) & $=\mathbf{0 . 9 1 2}$ & ICV (Poland) & $=\mathbf{6 . 6 3 0}$ \\
Impact Factor: & ISI (Dubai, UAE) $=\mathbf{0 . 8 2 9}$ & PUHL (Russia) $=\mathbf{0 . 1 5 6}$ & PIF (India) & $=\mathbf{1 . 9 4 0}$ \\
& GIF (Australia) $=\mathbf{0 . 5 6 4}$ & ESJI (KZ) $=\mathbf{8 . 7 1 6}$ & IBI (India) & $=\mathbf{4 . 2 6 0}$ \\
& JIF & $\mathbf{1 . 5 0 0}$ & SJIF (Morocco) $=\mathbf{5 . 6 6 7}$ & OAJI (USA) & $\mathbf{0 . 3 5 0}$ \\
\hline
\end{tabular}

Table 6. Agreement of the results of determination of analytes obtained by two methods in rock salt samples according to Fisher and Student's t-test. $(n=5 ; P=0.95)$.

\begin{tabular}{|c|c|c|c|c|c|c|}
\hline \multirow[t]{2}{*}{ Name of the sample } & $F$ & $t_{1,2}$ & $F$ & $t_{1,2}$ & $F$ & $t_{1,2}$ \\
\hline & \multicolumn{2}{|l|}{$\mathrm{Zn}$} & \multicolumn{2}{|l|}{$\mathrm{Mn}$} & \multicolumn{2}{|l|}{$\mathrm{Fe}$} \\
\hline Mine № 1,3 & 5.10 & 1.60 & 5.34 & 1.77 & 5.35 & 1.77 \\
\hline Mine № 4 & 5.25 & 1.50 & 5.35 & 1.76 & 5.34 & 1.78 \\
\hline Mine № 7 & 5.18 & 1.50 & 5.34 & 1.78 & 5.36 & 1.78 \\
\hline $\begin{array}{ll}\text { Mine } & \text { of } \\
\text { Volodarsky }\end{array}$ & 5.01 & 1.56 & 5.35 & 1.79 & 5.35 & 1.79 \\
\hline & $F_{\text {таблл. }}=6.34$ & $t_{\text {табл }}=2.78$ & $F_{\text {табл. }}=6.34$ & $t_{\text {табл. }}=2.78$ & $F_{\text {табл }}=6.34$ & $t_{\text {таблл }}=2.78$ \\
\hline
\end{tabular}

Table 7. Estimation of the systematic error in the atomic absorption determination of Zinc, Iron, and Manganese by varying the mass of sample swab.

\begin{tabular}{|c|c|c|c|}
\hline $\begin{array}{l}\text { Element, } \\
\text { Name of the sample }\end{array}$ & Mass of the sample, $g$ & $\begin{array}{c}\text { Concentration, } \mathrm{mg} / \mathrm{kg} \\
\bar{C} \pm \frac{t_{p, f} S}{\sqrt{n}}\end{array}$ & $S_{r}$ \\
\hline \multirow{3}{*}{$\begin{array}{l}\text { Zinc, } \\
\text { mine № } 1,3\end{array}$} & 0.2612 & $12.29 \pm 0.05$ & 0.01 \\
\hline & 0.3621 & $12.24 \pm 0.08$ & 0.01 \\
\hline & 0.4268 & $12.35 \pm 0.06$ & 0.01 \\
\hline \multirow{3}{*}{$\begin{array}{l}\text { Zinc, } \\
\text { Mine № } 4\end{array}$} & 0.2609 & $8.61 \pm 0.04$ & 0.01 \\
\hline & 0.3633 & $8.59 \pm 0.04$ & 0.01 \\
\hline & 0.4461 & $8.54 \pm 0.05$ & 0.01 \\
\hline \multirow{3}{*}{ mine №7 } & 0.2603 & $9.40 \pm 0.05$ & 0.01 \\
\hline & 0.3203 & $9.48 \pm 0.04$ & 0.01 \\
\hline & 0.4258 & $9.43 \pm 0.04$ & 0.01 \\
\hline \multirow{3}{*}{$\begin{array}{l}\text { Zinc, } \\
\text { mine of Volodarsky }\end{array}$} & 0.2593 & $9.80 \pm 0.05$ & 0.01 \\
\hline & 0.3432 & $9.79 \pm 0.03$ & 0.01 \\
\hline & 0.4197 & $9.84 \pm 0.03$ & 0.01 \\
\hline \multirow{3}{*}{$\begin{array}{l}\text { Iron, } \\
\text { mine № } 1,3\end{array}$} & 0.2612 & $11.68 \pm 0.06$ & 0.01 \\
\hline & 0.3623 & $11.70 \pm 0.04$ & 0.01 \\
\hline & 0.4268 & $11.72 \pm 0.05$ & 0.01 \\
\hline \multirow{3}{*}{$\begin{array}{l}\text { Iron, } \\
\text { Mine № } 4\end{array}$} & 0.2609 & $14.04 \pm 0.05$ & 0.01 \\
\hline & 0.3633 & $13.98 \pm 0.03$ & 0.01 \\
\hline & 0.4461 & $14.01 \pm 0.05$ & 0.01 \\
\hline \multirow{3}{*}{ mine №7 ${ }^{\text {Iron, }}$} & 0.2603 & $15.59 \pm 0.04$ & 0.01 \\
\hline & 0.3203 & $15.61 \pm 0.04$ & 0.01 \\
\hline & 0.4258 & $15.58 \pm 0.05$ & 0.01 \\
\hline \multirow{3}{*}{$\begin{array}{l}\text { Iron, } \\
\text { mine of Volodarsky }\end{array}$} & 0.2593 & $17.87 \pm 0.04$ & 0.01 \\
\hline & 0.3432 & $17.91 \pm 0.04$ & 0.01 \\
\hline & 0.4197 & $17.86 \pm 0.05$ & 0.01 \\
\hline Name of the sample & \multicolumn{3}{|l|}{ Manganese } \\
\hline Mine № 1,3 & 0.2612 & $3.14 \pm 0.05$ & 0.01 \\
\hline Mine № 4 & 0.3609 & $2.78 \pm 0.03$ & 0.01 \\
\hline Mine № 7 & 0.4603 & $4.27 \pm 0.05$ & 0.01 \\
\hline Mine of Volodarsky & 0.5593 & $3.75 \pm 0.04$ & 0.01 \\
\hline
\end{tabular}




\begin{tabular}{llllll} 
& ISRA (India) $=\mathbf{3 . 1 1 7}$ & SIS (USA) & $=\mathbf{0 . 9 1 2}$ & ICV (Poland) & $=\mathbf{6 . 6 3 0}$ \\
Impact Factor: & ISI (Dubai, UAE) $=\mathbf{0 . 8 2 9}$ & PUHL (Russia) $=\mathbf{0 . 1 5 6}$ & PIF (India) & $=\mathbf{1 . 9 4 0}$ \\
& GIF (Australia) $=\mathbf{0 . 5 6 4}$ & ESJI (KZ) & $=\mathbf{8 . 7 1 6}$ & IBI (India) & $=\mathbf{4 . 2 6 0}$ \\
& JIF & $\mathbf{1 . 5 0 0}$ & SJIF (Morocco) $=\mathbf{5 . 6 6 7}$ & OAJI (USA) & $\mathbf{0 . 3 5 0}$ \\
\hline
\end{tabular}

\section{References:}

1. Alzahrani, H. R., \& Kumakli, H. (2016). Arabian Journal of Chemistry. V.1(163). pp. 605-623.

2. Kulek de Andrade, C., et al. (2017). J. Food. Chem. - DOI: http://dx.doi.org/10.1016/j.foodchem.2017.07.1 11

3. (2017). Mediko-biologichni vimogi ta sanitarni normi jakosti prodovol'choï sirovini harchovih produktiv. Dopovnennja № 3, Kyiv, vid-vo standartiv, p.234.

4. Macedo de Oliveira, R., et al. (2016). Microchemical Journal. V.1 (124), pp.402 - 409.

5. Rodriagues J. C.. (2008), J. Agric. Food. Chem. V. 1 (59).pp. $6616-6623$.

6. Almeida, J. S., Souza, O. C. C. O., \& Teixeira, L. S. G. (2017). Microchemical Journal. doi: 10.1016/j.microc.2017.09.012

7. Cindrić, I. J., et al. (2011). Microchemical Journal. V.1(99). pp.364 - 369.

8. Pereira Junior, J. B., Dantas, K. G. F. (2016). Food Chemistry.V. 1(196), pp.331 - 337.

9. Yanus, R. L., et al. (2014). Talanta, V.1(119), pp.1-4.

10. Orecchio, S., et al. (2014). Microchemical Journal. V.1(116), pp.163-172.

11. Schwertfeger, D. M., et al. (2016). Anal. Chem. DOI: $10.1021 /$ acs.analchem.6b02716

12. Orgheda, L. A. D. (2010). J.Acric.Food Chem. V.1(53), pp.7863- 7869 .

13. O`neil, G. D., Newton, M. E., \& Macpherson, Julie, V. (2015). Anal.Chem. Publication Date (Web) DOI: 10.1021/acs.analchem.5b00597.
14. Otaka, A., Hokura, A., \& Nakai, I. (2014). Food Chemistry V.1(147), pp.318-326.

15. Hutton, L. A., et al. (2014). J. Anal. Chem. V. 1(86), pp. $4556-4572$.

16. Hosic, S., Murthy, S. K., \& Koppes, A. N. (2015). Anal. Chem. DOI: 10.1021/acs.analchem.5b04077.

17. Pereira, C. C., et al. (2017). Food Chemistry., DOI:

http://dx.doi.org/10.1016/j.foodchem.2017.07.1 12

18. Clark, K. D., Zhang, C., Jared, L. (2016). Anal. Chem., DOI: 10.1021/acs.analchem.6b02935.

19. Smith, R. M. (2010). J. of. Chr. V.1(1000), pp.3-27.

20. Corona, T., Iglesias, M., \& Antico, E. (2014). J. Agric.Food.Chem., V.1(62), pp.5690 - 5698.

21. Yilmaz, E., \& Soylak, M. (2017). Talanta. V.1(174), pp.605-609.

22. Matusiewicz, H., Ślachciński, M. (2017). Microchemical Journal. V.1(130), pp.345 - 352.

23. de Paula, C. E. R., et al. (2016). Microchemical Journal. V. 127, pp.1-6.

24. Tautkus, S. (2010). J.Serb. Chem. Soc. V.5(69), pp.393-402.

25. Fakayode, S. O., et al. (2012). J. of Chem. Educat.V.1(89), pp.109- 113.

26. Mollo, A., et al. (2017). Microchemical Journal. DOI: $10.1016 /$ j.microc.2017.09.008. 